Meta

Journal des traducteurs

Translators' Journal

\title{
Corpus-based Interpreting Studies as an Offshoot of Corpus-based Translation Studies
}

\section{Miriam Shlesinger}

Volume 43, numéro 4, décembre 1998

L'approche basée sur le corpus

The Corpus-based Approach

URI : https://id.erudit.org/iderudit/004136ar

DOI : https://doi.org/10.7202/004136ar

Aller au sommaire du numéro

Éditeur(s)

Les Presses de l'Université de Montréal

ISSN

0026-0452 (imprimé)

1492-1421 (numérique)

Découvrir la revue

Citer cet article

Shlesinger, M. (1998). Corpus-based Interpreting Studies as an Offshoot of Corpus-based Translation Studies. Meta, 43(4), 486-493.

https://doi.org/10.7202/004136ar
Résumé de l'article

Cet article traite des avantages et inconvénients liés à l'application d'une méthodologie basée sur le corpus à l'étude de l'interprétation. L'auteur explore deux voies qui permettent d'utiliser avec profit l'étude de corpus pour la recherche en interprétation. La première est directe et demande l'élaboration de nouveaux types de corpus parallèles et de corpus comparables. La seconde consiste à utiliser un corpus monolingue pour l'extraction de données exploitables par la recherche expérimentale en interprétation. 


\title{
CORPUS-BASED INTERPRETING STUDIES AS AN OFFSHOOT OF CORPUS-BASED TRANSLATION STUDIES
}

\author{
MIRIAM SHLESINGER
}

Bar-Ilan University, Ramat-Gan, Israel

\begin{abstract}
Résumé
Cet article traite des avantages et inconvénients liés à l'application d'une méthodologie basée sur le corpus à l'étude de l'interprétation. L'auteur explore deux voies qui permettent d'utiliser avec profit l'étude de corpus pour la recherche en interprétation. La première est directe et demande l'élaboration de nouveaux types de corpus parallèles et de corpus comparables. La seconde consiste à utiliser un corpus monolingue pour l'extraction de données exploitables par la recherche expérimentale en interprétation.
\end{abstract}

\begin{abstract}
This article looks at the problems and benefits that may arise from applying a corpusbased methodology to the study of interpreting. It explores two ways in which interpreting could be fruitfully investigated with the aid of corpora. The first is direct and involves the design of new types of parallel and comparable corpora. The second consists of employing existing monolingual corpora to extract material that can be used in experimental research into interpreting.
\end{abstract}

\section{INTRODUCTION}

Corpus linguistics is a data-driven methodology for analysing large quantities of machine-readable running text. Simultaneous interpreting is a mode of interlingual processing in which both the input and the output are oral. Any attempt to apply corpus linguistics to simultaneous interpreting is bound to raise questions, not only about the feasibility of the exercise but also about its point. And yet, I would argue that corpus-based interpreting studies offer a tool which is both viable and revelatory not only for the study of interpreting, per se, but for translation studies as a whole. In what follows, I will attempt to examine the corpus-based methodology as it may be extended to interpreting, through (1) the creation of parallel and comparable corpora ${ }^{1}$ comprising discourse which is relevant to interpreting; and (2) the use of existing monolingual corpora as sources of materials for testing hypotheses about interpreting. To keep the issue clear, I will confine the discussion to conference interpreting in the spoken- (as opposed to signed-) language modality, in the simultaneous mode; in principle, much of what follows may be extended both to other settings (e.g. courtroom interpreting, business negotiations using oral bilingual mediation, etc.) and to other modes (e.g. consecutive interpreting) as well.

Interpreting may be (and often is) subsumed under translation. Nonetheless, just as translation is "a communicative event shaped by its own goals, pressures and context of production" (Baker 1996), so too is interpreting. For the purposes of this paper, how-

Meta, XLIII, 4, 1998 
ever, the term translation is used to refer exclusively to the production of a written output based on written other-language input. The term interpreting refers to the production of oral output based on other-language input which may be either written (to be read) or unwritten (impromptu). It has been established that each of these modes may at times be characterized by features more typical of the other (e.g. Enkvist 1982b; Halliday 1989; Stubbs 1996), and that they often overlap. In the case of inputs typical of conference settings, this overlap is all the more noticeable. Many of the papers are just that - written documents; yet their delivery is oral, generally at a faster-than-average pace, in a formal, unidirectional mode of presentation. Thus, the interpreter's task typically consists of rendering either an impromptu piece of discourse or written document being read, without interruption, by a single presenter. The absence of interlocutors and the length of the discourse to be interpreted have been cited as major factors in determining its lexical, syntactic and stylistic features (Beaugrande 1992: 221-246; Stubbs 1996: 74). ${ }^{2}$

\section{BENEFITS AND DRAWBACKS OF USING CORPUS-BASED TRANSLATION STUDIES FOR THE STUDY OF ORAL DISCOURSE}

Many of the observations encountered in the literature on interpreting are based on sparse, often anecdotal data; i.e. observations from the limited number of outputs that the writer has had the opportunity to listen to, usually as a fellow practitioner. ${ }^{3}$ Alternatively, more for reasons of expediency than ecological validity, researchers of interpreting (myself included) draw heavily upon the output of students and trainees. While students' outputs are no less valid as an object of study than those of professional interpreters, the differences between the two target populations argue against applying findings from one group to the other. Recruiting professional interpreters for experimental research is a sensitive, often frustrating exercise, all the more so in view of the relatively small number of "subjects" for any given language combination in any given place. ${ }^{4}$

From the standpoint of interpreting research, the compilation of bilingual and parallel corpora is indeed overdue, given the potential to use large, machine-readable corpora to arrive at global inferences about the interpreted text (1) in relation to other forms of oral discourse; and (2) in relation to other forms of translation. This brings us back to the question of whether corpus-based translation studies are applicable to simultaneous interpreting.

If indeed "the ease of use of a technology subtly shapes the paradigm of what we want" (Monaghan 1995: 62), then any developments towards a full-fledged paradigm of corpus-based interpreting studies will depend on our success in overcoming two main obstacles.

\subsection{Transcription}

While the input (i.e. the conference presentations, or at least those which are based on a written paper) may often be available in machine-readable (or easily convertible) form, the interpreters' output is not. For all the advances of modern technology, transcription is still a labour-intensive and arduous process, which poses a major methodological hurdle. ${ }^{5}$ The difficulty lies not only in the act of transcription, per se, but in the fact that certain elements of spoken communication are both so subtle and so subjective as to defy description (Cook 1995: 51-52; O'Connell et al. 1993). To strike the golden mean between what is desirable and what is feasible, it might be more appropriate, for the time being at least, to make do with smaller, carefully constructed 
sample corpora, as suggested by Johansson (1992) with respect to "texts which are not readily available in machine-readable form."

\subsection{The Paralinguistic Dimensions}

While transcription, however laborious, can provide us with a representation of the interpreter's linguistic output, its failure to reflect the concomitant paralinguistic dimensions is a major drawback. And yet, this is a situation we have to live with, at least until the necessary technological breakthroughs allow us to represent prosodic and temporal features in machine-readable and easily recognizable form - including those salient prosodic features that set interpreting apart from all other forms of oral discourse (Shlesinger 1994; Williams 1995). Clearly, it is also essential to establish a shared system of conventions for encoding auditory data ${ }^{6}$ (Berk-Seligson 1990: 50-51; Kalina 1994). Thus, given the subtleties of intonational and other paralinguistic parameters, it may be prudent to concede that the application of corpus linguistics to interpreting had best be limited at this point in time to features which lend themselves to transcription.

\section{CORPORA AS A RESOURCE IN DESCRIPTIVE INTERPRETING STUDIES}

What will the application of corpus linguistics reveal about interpreting? To begin with, it will reveal what corpus linguistics has long been known to reveal about all corpora to which it is applied: frequencies of words, grammatical constructions, discourse patterns, co-occurrences, lexical density, type-token ratios, etc. In addition, interpreting could be then be studied through the use of two types of corpora, in effect extending two increasingly important applications of corpus-based translation studies into this area of research (Baker 1995; Laviosa 1998).

\subsection{Comparable Corpora}

Ideally, the notion of comparable corpora in interpreting studies should be extended to cover setting up three separate collections of texts in the same language: interpreted texts, original oral discourses delivered in similar settings, and written translations of such texts. This would allow for the identification of patterns specific to interpreted texts (regardless of their source language) as pieces of oral discourse, in relation to comparable texts in the same language. It would also allow us to identify the patterns which single out interpreted texts as distinct oral translational products in a given language irrespective of their source languages, through comparisons with comparable written translational products. It is through studies such as these, based on a large body of texts, that the characteristics of interpreting qua interpreting may be discerned. In other words, it is through studies such as these that one may hope to learn more about features which appear to cut across genres, languages and individuals. In addition, some of the features which may eventually be discerned will serve to substantiate hitherto untested observations about limitations on processing capacity (Gile 1991); others may provide a more systematic description of the shifts effected by interpreting (Shlesinger 1989a, 1995).

Baker (1993) has called for the development of specific methods and tools for interrogating large corpora of both original and translated texts, in order to explore what it is that makes these different from other objects of study (such as language in general or indeed any other kind of cultural interaction) and to observe "the principles that govern translational behaviour and the constraints under which it operates." Towards this end, she stresses the need to study "substantial amounts" of "real data" in order to move away from the preoccupation with instances in isolation. One aim of 
such studies has been to describe those features which appear to be universal in "translated text as a mediated communicative event" (p. 243). The same applies to interpreting studies, which has thus far suffered from the unavailability of large, computerized corpora. This methodological flaw was compounded by the intrinsic evanescence of interpreting, and by the fact that most interpreters are exposed to the outputs of no more than a handful of colleagues, in stark contrast to written translation where source and target texts are available in large quantities. Thus, for example, not until corpusbased interpreting studies are systematically applied will it be possible to discern with any degree of certainty those norms which transcend linguistic and geographical boundaries (cf. Toury 1980, 1995; Shlesinger 1989b; Harris 1990).

\subsection{Parallel Corpora}

Studies of interpreted texts in relation to their source-language counterparts may help in discerning language-specific (and direction-specific) features of the interpreted output, as well as a wide range of subjective, linguistic, textlinguistic and other features which may or may not be specific to this form of translation. In addition to languagepair-specific factors and personal variables (e.g. gender, extent of experience, language background) which are now routinely taken into account in corpus-based studies of written translations (Baker 1996; Laviosa 1998), a corpus-based analysis of interpreters' outputs may also be expected to reveal interactions between translational patterns and modality. (A well-known example concerns simultaneous interpretation from German, in which the verb or verb particle is often sentence-final, into languages in which the verb must appear in an earlier position. Hypotheses about the strategies involved in such language pairs and the nature of the target-language output could be effectively tested through the use of parallel corpora; while small-scale studies, based on isolated outputs of no more than ten interpreters, have produced tentative results, a computerized analysis of a much larger collection of inputs and outputs would produce findings which are both more detailed and more robust.) Contrasting these with written translational outputs would serve to distinguish the modality-specific factors from those which apply to the language pair concerned, on the one hand, and from factors which apply to translated texts, in general, on the other. Again, three collections would be called for: source-language texts, the corresponding interpreted versions, and the corresponding written translations, where available. ${ }^{7}$ As with smaller-scale studies along these lines, computerized comparisons between oral and written translations of the same source texts will provide a means of assessing the extent to which the functional juxtaposition of two languages is modality-dependent.

\section{EXISTING MONOLINGUAL CORPORA AS A RESOURCE IN EXPERIMENTAL INTERPRETING STUDIES}

Of the many paradigms which hold promise for the study of interpreting, those of cognitive psychology seem particularly relevant, even if methodologically problematic. The painstaking micro-level analyses which prevail in psychological experimentation seem to go against the grain of interpreting, with its plethora of situational, contextual, textual and subjective variables. And yet, there have been recurrent appeals to bridge the two. ${ }^{8}$ While researchers from within the profession and outside it have agreed, in principle, that controlled experimentation is vital, the actual design and methodology have proven to be a stumbling block. Even within the cognitive disciplines, such experimentation is frequently challenged on the grounds that laboratory settings are artificial, materials are context-free, tests almost invariably involve intentional learning 
instructions, and the tasks and manipulations bear little or no resemblance to any everyday activity. Counter-arguments center on the view that ecological validity need not mean the abandonment of the experimental method, that ongoing research holds potential for functionally relevant results - for which Neisser (1967), Flores d'Arcais (1978) and Massaro (1978) cite simultaneous interpreting as a case in point - and that generalizability is no less crucial than ecological validity (Bruce 1985; Rommetveit and Turner 1967; Gerver 1971: 141; Chernov 1979).

In interpreting research, too, the decoupling of experimental procedures from authentic conference settings has often been cited as undermining ecological validity (cf. Dillinger 1989; Gile 1994). Any attempt to "tamper" with either settings or materials is regarded by some as defeating the very purpose of research. Simultaneous interpreting clearly involves meaningful, contextualized materials; the experimental use of decontextualized (or minimally contextualized) materials removed from the natural setting of a multilingual conference is considered suspect (but see Moser 1976: 15). Nonetheless, the use of a laboratory setting, of prerecorded texts and of linguistically controlled materials has proven necessary for a controlled examination of the large number of variables involved in interpreting.

In a study currently being undertaken ${ }^{9}$ to test the manner in which working memory (as defined by Baddeley and Hitch 1974) operates in the process of simultaneous interpreting in general, and as a function of rate of presentation in particular, the design of materials has proven to be particularly problematic, requiring control over such parameters as length and frequency of words, phonological patterns, implicit and explicit semantic features, potential cognateness, etc. Clearly, authentic conference presentations are extremely unlikely to yield a sufficiently large concentration of materials (whether at the level of whole texts, segments or even utterances) which meet predetermined stipulations with respect to this type of variable. Two alternatives present themselves: (1) artificial materials, designed expressly for experimental purposes; (2) authentic materials extrapolated from an existing corpus (or subcorpus) of the relevant genres, on the basis of the stipulations relevant to the particular experiment. By using the British National Corpus, and a specially written program for extrapolating the particular types of target strings required for the study, it has been possible to compile a list of authentic utterances which could then be used in experimental study. In the interest of greater ecological validity, the segments preceding and following these strings (totalling approximately forty sentences in each case) were also included in the design. Thus, rather than rendering completely artificial or decontextualized utterances, the interpreters were presented with authentic - albeit carefully selected - segments of texts.

Just as the corpus-based study of forensic texts was found to be lacking so long as no corpora of dictated texts had been compiled (Coulthard 1994), so too a study of translated texts would seem to warrant the inclusion of (sub)corpora designed expressly for the study of interpreting. It is not difficult to imagine other ways in which such corpora may serve as rich sources of linguistic data for extrapolating the kinds of strings or utterances or complete pieces of discourse containing whatever parameters are relevant to the hypotheses being explored.

\section{CONCLUSION}

Both the collection and the selection of materials have been frequent bones of contention in interpreting research, and the use of corpora is bound to alleviate some of the most pressing methodological problems. Recent discussions in corpus-based translation studies have, in at least one instance (Baker 1996), cited evidence from 
interpreting as a case in point; i.e. interpreting is implicitly included in this fledgling field as a natural extension of its inclusion in the mapping of descriptive translation studies (Holmes 1988b; Toury 1995). Recourse to interpreting as part of corpus-based translation studies may indeed help to focus attention on what sets interlingual mediation apart, regardless of modality. By the same token, however, while continuing to explore the common ground, the corpus-based study of interpreting will also help to define what sets it apart. Both aims are very much in keeping with the agenda of its parent discipline, Translation Studies. Like it, the study of interpreting may finally have "reached a stage in its development as a discipline when it is ready for and needs the techniques and methodology of corpus linguistics in order to make a major leap from prescriptive to descriptive statements, from methodologizing to proper theorising, and from individual and fragmented pieces of research to powerful generalisations" (Baker 1993: 248).

\section{Notes}

1. As defined in Baker (1995), parallel corpora consist of original, source-language texts in languge A and their translated version in language B. Comparable corpora consist of separate collections of texts in the same language, one comprising original texts in the language in question and the other comprising translations in that language from a given source language or set of source languages.

2. The categorization of conferences into monster-conference and thematic conference (Beaugrande 1992) may have implications for the interpreter as well. The former is typified by a multitude of parallel sessions, and its subject matter is inherently diffuse. Thus, the interpreter - - who is rarely on a par with the direct addressees (the conference participants) when it comes to the sharing of situational and contextual knowledge - - is at a disadvantage, as s/he renders a sequence of papers, each in a different domain and each based on different assumptions about the listeners. Thematic conferences, on the other hand, have the advantage (for the participants, as well as the interpreter) of greater coherence, deriving from a more clearly delineated agenda of ideas, issues and topics. The delineation of the genres and text types relevant to a study based on texts used in conference settings is a subject unto itself, and will not be dealt with here (cf. Kopczynski 1982; Déjean le Féal 1982; Shlesinger 1989a; Biber and Finegan 1992).

3. Introspective data are rare and of questionable value, unless accompanied by recordings, preferably in dual-track format to include the original speaker as well; online observations of one's own output in the course of actual interpreting is unlikely to yield meta-textual or other insights which would withstand the test of either replicability or objectivity.

4. There is also the no less sensitive matter of receiving permission to use such recordings in research projects. This requirement, with all it entails, would of course apply to the corpus-based approach described below as well.

5. This is the main reason cited in the manual of the British National Corpus (Burnard 1995) for the fact that spoken outputs account for only ten percent of the texts. These limitations were dictated by "what was feasible within the constraints of the BNC project" (p. 19).

6. This is all the more true when one considers that, in the case of parallel corpora, the corresponding features in the source-language discourse and the synchrony between the two outputs must also be represented. The answer may lie in the direction outlined by Chafe et al. (1992) with respect to a corpus of spoken English, in which the transcription into standard English orthography will be linked with sound, allowing linguists and speech researchers to examine the relation of auditory phenomena to linguistic elements. As for kinesic and proxemic features, these are of only marginal importance in simultaneous interpreting, since the interpreter is not usually observed, and does not have recourse to body language as a communicative device; in consecutive and liaison interpreting, however, no analysis could be considered complete without taking such features into account (Poyatos 1987).

7. It is not uncommon for conference presentations to be translated (in writing), independent of their original setting.

8. "Given the fascinating aspects of the skill of the interpreter, one is amazed by the lack of interest of the behavioural sciences at large for this skill [...] the task could be a paradigmatic case for testing theories on language understanding on language production, etc. [...] there are probably very few 'real life' situations which are more similar to a laboratory of psychological experimentation than the situation of the interpreter in a conference booth ..." (Flores d'Arcais 1978: 386, 393).

9. Shlesinger, Miriam (in prep.): "Working Memory in Simultaneous Interpreting", PhD Thesis, Bar-Ilan University, Ramat-Gan, Israel. 


\section{REFERENCES}

AIJMER, Karin and Bengt ALTENBERG (Eds) (1992): English Corpus Linguistics, London/New York, Longman.

BADDELEY, Alan D. and Graham HITCH (1974): "Working Memory", Bower (Ed.), The Psychology of Learning and Motivation: Advances in Research and Theory, Volume 8, New York/San Francisco/ London, Academic Press, pp. 47-89.

BAKER, Mona (1993): "Corpus Linguistics and Translation Studies: Implications and Applications", Baker et al. (Eds), Text and Technology, Philadelphia/Amsterdam, John Benjamins, pp. 233-250.

BAKER, Mona (1995): "Corpora in Translation Studies: An Overview and Some Suggestions for Future Research", Target, 7 (2), pp. 223-243.

BAKER, Mona (1996): "Corpus-based Translation Studies: the Challenges that Lie Ahead", Harold Somers (Ed.), Terminology, LSP and Translation: Studies in Language Engineering, in Honour of Juan C. Sager, Amsterdam/Philadelphia, John Benjamins, pp. 175-186.

BAKER, Mona, GILL, Francis and Elena TOGNINI-BONELLI (Eds) (1993): Text and Technology, Amsterdam/Philadelphia, John Benjamins.

BEAUGRANDE, Robert de (1992): "Consultations, Conferences, and Proceedings: Their Role as Discourse Transactions", de Beaugrande et al. (Eds), Language, Discourse and Translation in the West and Middle East, Amsterdam/Philadelphia, John Benjamins, pp. 221-246.

BEAUGRANDE, Robert de, SHUNNAQ, Abdulla and Mohamed HELMY HELIEL (Eds) (1992): Language, Discourse and Translation in the West and Middle East, Amsterdam/Philadelphia, John Benjamins.

BERK-SELIGSON, Susan (1990): The Bilingual Courtroom: Court Interpreters in the Judicial Process, Chicago/London, University of Chicago Press.

BIBER, Douglas and Edward FINEGAN (1992): "On the Exploitation of Computerized Corpora in Variation Studies", Aijmer and Altenberg (Eds), English Corpus Linguistics, London/New York, Longman, pp. 204-220.

BOWER, Gordon H. (Ed.) (1974): The Psychology of Learning and Motivation: Advances in Research and Theory, Volume 8, New York/San Francisco/London, Academic Press.

BRUCE, Darryl (1985): "The How and Why of Ecological Memory", Journal of Experimental Psychology: General, 114 (1), pp. 78-90.

BURNARD, Lou (Ed.) (1995): British National Corpus: Users Reference Guide for the British National Corpus, Oxford University Computing Services.

CHAFE, Wallace L., DU BOIS, John W. and Sandra A. THOMPSON (1992): "Towards a New Corpus of Spoken American English", Aijmer and Altenberg (Eds), English Corpus Linguistics, London/New York, Longman, pp. 64-82.

CHERNOV, Ghelly (1979): "Semantic Aspects of Psycholinguistic Research in Simultaneous Interpretation", Language and Speech, 22 (3), pp. 277-295.

COOK, Guy (1995): "Theoretical Issues: Transcribing the Untranscribable", Leech et al. (Eds), Spoken English on Computer: transcription, mark-up and application, New York, Longman, pp. 35-53.

COULTHARD, Malcolm (1994): "On the Use of Corpora in the Analysis of Forensic Texts", Forensic Linguistics: The International Journal of Speech, Language and the Law, 1 (1), p. 2743.

DÉJEAN LE FÉAL, Karla (1982): "Why Impromptu Speech Is Easy To Understand", Enkvist (Ed.), Impromptu Speech: A Symposium, Åbo, Åbo Akademi, pp. 221-239.

DILlINGER, Michael L. (1989): Component Processes of Simultaneous Interpreting, Unpublished PhD Thesis, McGill University, Montreal.

DOLLERUP, Cay and Anne LODDEGAARD (Eds) (1994): Teaching Translation and Interpreting 2: Insights, Aims and Visions, Amsterdam/Philadelphia, John Benjamins.

ENKVIST, Nils (Ed.) (1982a): Impromptu Speech: A Symposium, Åbo, Åbo Akademi.

ENKVIST, Nils (Ed.) (1982b): "Impromptu Speech, Structure and Process", Enkvist (Ed.), Impromptu Speech: A Symposium, Åbo, Åbo Akademi, pp. 11-32.

FLORES D'ARCAIS, Giovanni (1978): "The Contribution of Cognitive Psychology to the Study of Interpretation", Gerver and Sinaiko (Eds), Language, Interpretation and Communication: NATO Symposium on Language, Interpretation and Communication, Venice, 1977, New York, Plenum Press, pp. 385-402.

GERVER, David (1971): Simultaneous Interpretation and Human Information Processing, Unpublished PhD Thesis, Oxford University.

GERVER, David and H. Wallace SINAIKO (Eds) (1978): Language, Interpretation and Communication: NATO Symposium on Language, Interpretation and Communication, Venice, 1977, New York, Plenum Press.

GILE, Daniel (1991): "The Processing Capacity Issue in Conference Interpretation", Babel, 37, pp. 15-27. 
GILE, Daniel (1994): "Methodological Aspects of Interpretation and Translation Research", Lambert and Moser-Mercer (Eds), Bridging the Gap: Empirical Research in Simultaneous Interpretation, Amsterdam / Philadelphia, John Benjamins, pp. 39-56.

HALLIDAY, M. A. K. (1989): Spoken and Written Language, Second edition, Oxford, Oxford University Press.

HARRIS, Brian (1990): "Norms in Interpretation", Target: International Journal of Translation Studies, 2 (1), pp. 215-219.

HOLMES, James S. (Ed.) (1988a): Translated!: Papers on Literary Translation and Translation Studies, Amsterdam, Rodopi.

HOLMES, James S. (1988b): "The Name and Nature of Translation Studies", Holmes (Ed.), Translated!: Papers on Literary Translation and Translation Studies, Amsterdam, Rodopi, pp. 81-91.

JOHANSSON, Stig (1992): "Times Change, and So Do Corpora", Aijmer and Altenberg, (Eds), English Corpus Linguistics, London/New York, Longman, pp. 305-314.

KALINA, Sylvia (1994): "Analyzing Interpreters' Performance: Methods and Problems", Dolleterrup and Loddegaard (Eds), Teaching Translation and Interpreting 2: Insights, Aims and Visions, Amsterdam/ Philadelphia, John Benjamins, pp. 217-224.

KOPCZYNSKI, Andrzej (1982): "Effects of Some Characteristics of Impromptu Speech on Conference Interpreting", Enkvist (Ed.), Impromptu Speech: A Symposium, Åbo, Åbo Akademi, pp. 255-267.

LAMBERT, Sylvie and Barbara MOSER-MERCER (1994): Bridging the Gap: Empirical Research in Simultaneous Interpretation, Amsterdam/Philadelphia, John Benjamins.

LAVIOSA, Sara (1998): "The English Comparable Corpus: a Resource and a Methodology", Lynne Bowker, Michael Cronin, Dorothy Kenny and Jennifer Pearson (Eds), Unity in Diversity? Current Trends in Translation Studies, Manchester, St. Jerome Publishing.

LEECH, Geoffrey, MYERS, Greg and Jenny THOMAS (Eds) (1995): Spoken English on Computer: Transcription, Mark-up and Application, New York, Longman.

MASSARO, Dominic (1978): "An Information-Processing Model of Understanding Speech", Gerver and Sinaiko (Eds), Language, Interpretation and Communication: NATO Symposium on Language, Interpretation and Communication, Venice, 1977, New York, Plenum Press, pp. 299-314.

MONAGHAN, James (1995): "Whole-Text Analysis in Computerized Spoken Discourse", Leech et al. (Eds), Spoken English on Computer: Transcription, Mark-up and Application, New York, Longman, pp. 62-68.

MOSER, Barbara (1976): Simultaneous Translation: Linguistic, Psycholinguistic and Human Information Processing Aspects, Unpublished doctoral dissertation, Innsbruck University.

NEISSER, Ulric (1967): Cognitive Psychology, Englewod Cliffs, New Jersey, Prentice-Hall.

O'CONNELL, Daniel C., KOWAL, S. J. and Sabine KOWAL (1993): "Some Sources of Error in the Transcription of Real Time in Spoken discourse", The Jerome Quarterly, 8 (3), pp. 3-11.

POYATOS, F. (1987): "Nonverbal Communication in Simultaneous and Consecutive Interpretation: A Theoretical Model and New Perspectives", TEXTconTEXT, 2, pp. 73-108.

ROMMETVEIT, Ragnar and Elizabeth Ann TURNER (1967): "A Study of 'Chunking' in Transmission of Messages", Lingua, 18, pp. 337-351.

SHLESINGER, Miriam (1989a): Simultaneous Interpretation as a Factor in Effecting Shifts in the Position of Texts on the Oral-Literate Continuum, Tel Aviv, Tel Aviv University, unpublished M.A.

SHLESINGER, Miriam (1989b): "Extending the Theory of Translation to Interpretation: Norms as a Case in Point", Target: International Journal of Translation Studies, 1 (1), pp. 111-116.

SHLESINGER, Miriam (1994): "Intonation In the Production and Perception of Simultaneous Interpretation", Lambert and Moser-Mercer (Eds), Bridging the Gap: Empirical Research in Simultaneous Interpretation, Amsterdam/Philadelphia, John Benjamins, pp. 225-236.

SHLESINGER, Miriam (1995): "Shifts in Cohesion in Simultaneous Interpreting", The Translator, 1 (2), pp. 193-214.

STUBBS, Michael (1996): Text and Corpus Analysis, Oxford, Blackwell.

TOURY, Gideon (1980): In Search of a Theory of Translation, Tel Aviv, The Porter Institute for Poetics and Semiotics, Tel Aviv University.

TOURY, Gideon (1995): Descriptive Translation Studies and Beyond, Amsterdam/Philadelphia, John Benjamins.

WILLIAMS, Sarah (1995): "Observations on Anomalous Stress in Interpreting", The Translator, 1 (1), pp. 47-64. 